\title{
Unlocking Potentials in Developing Country through Education: A Panacea for Economic Growth and Poverty Alleviation
}

\author{
M.B.I. Omoniyi \\ Department of Guidance \& Counselling \\ Adekunle Ajasin University, \\ Akungba Akoko, Ondo State, Nigeria
}

\author{
A.O. Omoniyi \\ Department of Science \& Technical \\ Education \\ Adekunle Ajasin University, \\ Akungba Akoko, Ondo State,Nigeria
}

\begin{abstract}
Poverty continues to be the major issue confronting several developing economies around the world. In Nigeria particularly, poverty remains a major problem manifesting itself in several indicators of socio-economic well being such as life expectancy, literacy level, crime rate, terrorism to mention but a few. It seems obvious that most poor people in Nigeria cannot provide the basic needs of life for themselves. Successive government has been noted to have made efforts towards poverty alleviation to no avail. This paper focus on the importance of education as the major tool for alleviating poverty, as no country can succeed in becoming wealthy without educating her people. Education holds the key to expand opportunity, power to escape poverty, influence major decisions and leads to more secure and fulfilled life. The paper further made recommendations to Nigeria government towards the adequate running and funding of her educational institutions as the appropriate step to be taken in order to alleviate poverty among her citizens.
\end{abstract}

\section{Introduction}

Contemporary world attention is today focused on education as an instrument of launching nations into the world of science and technology and with consequential hope of human advancement, in terms of living conditions and development of the environment. This is because education in the life of any nation, is the live wire of its industries. It is the foundation of moral regeneration and revival of its people. Education is the force and bulwark of any nation's defence. Therefore, no nation can afford to pay lip service to the education of its people. The nation that thinks lightly of education does so at its own peril as no nation rises above the level of its education. The Federal Government of Nigeria has accorded due recognition to the global clamour for Education for All (EFA) as a veritable instrument of social and political mobilization and economic development. This is in keeping with the set objectives of according the citizenry free, compulsory and qualitative education to all school age children for the first nine years of schooling in order to ensure compliance with the EFA and the Millennium Development goals. In this regard, the Government signed into law, the compulsory, free Universal Basic Education Act, 2004 and other Related Matters, which was a positive step in the right direction, aimed at actualising the stated goals. As laudable and positive as the Universal Basic Education programme and education in the higher institutions of learning may be, it will not do Nigeria any good as long as there is no efficient implementation of these programmes. Many children of school age still hawk and roam around the streets during school hours. All laws made so far to stop this menace have never been implemented. Cursory observations show that there is currently a major decline in the Nigeria education sector. [7], observed that the World Economic Forum Surveyed 131 countries including Nigeria, the published results in Global Competitiveness Report 2007-2008 indicated that Nigeria ranks No.102, a bottom position. According to this report Nigeria ranks lower in quality of higher education than even enrolment. Cursory observations also show that learning environment is seriously compromised at all levels. There is the issue of over-congested classrooms at the primary and secondary levels. In the higher institutions, overcrowded laboratories where the taps have no water and there is, most of the time no electricity to run the equipment are other issues to contend with. Compared with other parts of the world and even with other African countries, Nigeria's level of public funding of education today seem to be dismal. The United Nations (UN) agency recommended as high as $26 \%$ of Gross Domestic Product (GDP) to be devoted in the budget to the education sector. In a recent survey by the United Nations Educational Scientific and Cultural Organisation, (UNESCO), Nigeria ranked last among 136 countries surveyed by the organisation, with 
reference to public spending on education as a proportion of Gross Domestic Product [16]. According to him, the survey found that the country's proportion of public spending on education as a percentage of the GDP was 0.89 percent, while Nigeria's education expenditure as a proportion of Grass National Income (GNI) was also poor, 0.85 percent, or 167 th out of 168 countries. [9], also observed that in previous decades, Nigeria was higher up the ranking in terms of education expenditure as a proportion of GNI. According to him, in 1981, Nigeria ranked 40th with 5.11 percent GNI, 78th in 1975 with 3.32 percent GNI. By 1993, the country's ranking and figures had plummeted and Nigeria ranked 154 among 155 countries surveyed with 0.85 percent GNI. He therefore noted that these figures were indications of misplaced priorities by Nigeria government. It is no wonder then that the Nigeria education sector is presently below the standard of what it should be in many fundamental respects. The Nigeria education sector is currently a dilapidated arena for perpetual crises, characterised by perennial staff strikes, student's demonstrations and riots. Education is more than reading writing and arithmetic. It is one of the most important investments a country can make in its people and is critical to unlocking potentials and reducing poverty and inequality.

\section{Dynamics of Poverty}

According to [17], if all students in low income countries left school with basic reading skills, 171 million people could be lifted out of poverty. This is equal to a $12 \%$ cut in global poverty. They also observed that one extra year of schooling increases an individual's earning by up to $10 \%$ and each additional year of schooling raises average gross domestic product (GDP) growth by $0.37 \%$. [18], observed that an increase of one standard deviation in student scores on international assessments of literacy and mathematics is associated with a $2 \%$ increases in annual GDP per capita growth. Poverty is the World's current greatest threat to peace and stability more than terrorism and other highly publicized struggles. According to [15], more than eight million people around the world die each year because they are too poor to stay alive. In the year 2010, the United Nation Development Project (UNDP) estimated roughly that 1.4 billion people were living in extreme poverty, of these, about $93 \%$ live in regions; East Asia, South Asia and SubSaharan Africa. In Nigeria, despite the government's poverty eradications campaigns, national development plans and sessional papers, poverty is still a major challenge. It is also recognised by all and sundry as a major threat to the very existence of Nigeria as a country. It may not be easy to have a universal definition to poverty as it is viewed from different angles by researchers. However, according to [15], poverty can be defined in terms of three distinguishable degrees. These are: Extreme poverty, moderate poverty and relative poverty. Extreme poverty means the household cannot meet basic needs for survival. Such people are perpetually hungry, unable to access health care; they lack amenities of safe drinking water and sanitation. They cannot afford education for their children and cannot shelter their families. Moderate poverty on the other hand generally refers to conditions of life in which basic needs are met, but just barely. Relative poverty is construed as a household income level below a given proportion of average national income. In high income countries, they lack access to cultural goods, entertainment, recreation, quality health care, education and other prerequisites for upward social mobility. The World Bank has been defining poverty in statistical terms of income of one US dollar per person per day, measured at purchasing power parity to determine the number of extreme poor around the World. Cursory observations show that many Nigerians are living below the poverty level of one US dollar per day. The base line is that, many Nigerians live in poverty in its extreme nature manifesting itself in terms of lack of basic standard of health, nutrition, shelter, water and sanitations, and other minimum need for survival, well-being and participation in the society. It is very vital for Nigeria to unlock the potentials of her citizens through efficient qualitative and quantitative education for greater economic efficiency to alleviate poverty in its entire ramification. Moreover, if only from the point of the positive spill over and externalities of education, Nigeria government needs to take the education of her citizens more seriously. One of the externalities of education that readily comes to mind is the individual externality, in which an educated person especially at the tertiary level, confers great benefits on another person. Specific examples of this externality include better educated supervisors, better decision makers, better advisers and better planners. This will consequently raise the productivity of workers; there will be improvement in the lives of youth at all levels. There is an also positive family effect, whereby an educated child confers benefits on siblings, parents and inter-generational benefits, arising by raising children within a better school and home environments. Another category of externality comprises of community benefits which is derived from improvement of character of society and the quality of the social, economic and political decisions. The externality associated with public 
good aspect of education is also of great importance. This is derived from the fact that the widespread menu of tertiary education especially promotes higher level of literacy and comprehension among the population. This category of externality includes more favourable attitudes to growth, innovation and risk taking. It also results in cost of crime prevention; facilitates dissemination of credible information and enhances advance in knowledge, associated with investigation and research. Therefore, education in general serves two masters; it serves the individual and serves the nation. It is the only hope out of poverty; it is a value and must be a concern for all. Failure to maintain social integration and hope for poverty reduction leads to violence against property and persons. This in turn impact negatively on the economy and welfare of both poor and non poor.

\section{Education and Economic Development}

Education provides a foundation for eradicating poverty and fostering economic development. It is the groundwork on which much of economic and social well-being of the citizens is built. Education is the key to increasing economic efficiency and social consistency, by increasing the value and efficiency of the labour force and consequently raising the poor from poverty. Education increase overall productivity and intellectual flexibility of the labour force and ensures that a country is competitive in world market now characterized by changing technologies and production methods. According to [14], the primary determinants of a country's standard of living is how well it succeeds in developing and utilizing the skills and knowledge, and furthering the health and educating the majority of its population. No country has achieved constant economic development without considerable investment in education and human capital [12]. Many researchers have shown handsome returns to various forms of human capital accumulation, basic education, research, training and aptitude building [14], unequal education tends to have a negative impact on per capita income and thereby increase poverty in many countries. Educating girls and women is probably the single most effective investment a developing country like Nigeria can make, whether or not women work outside the home. It creates a multitude of positive remunerations for families including better family health and nutrition, improved birth spacing, lower infant and child mortality, and enhanced educational attainment of children. For a country to be adequately integrated in worlds market of manufactured goods, and compete in these markets and in globalizing service markets, will depend on the excellence of human capital they bring to the competition. Ensuring that all citizens are educated and numerate, that many possess a wide range of problem solving skills beyond the basic level, and that some have World professional skills will be an advantage.

\section{Education and Productivity}

Clearly the educational provisions within any given country represent one of the main determinants of the composition and growth of that country's output and exports. It constitutes an important ingredient in the system capacity to borrow foreign technology effectively. For example: primary and secondary education all raises the productivity of workers, rural and urban. Secondary education, including vocational, facilitates the acquisition of skills and managerial capacity while tertiary education supports the development of basic science, the appropriate selection of technology imports and the domestic adaptation and development of technologies. Secondary and tertiary education also represents critical elements in the development of key institution; of government, the law, and the financial system, among others, all of which are essential for economic growth. Empirical evidence at both micro and macro levels further illuminates these relationships. At a micro level, numerous studies indicate that increases in earnings are associated with additional years of education, with the rate of return varying with high level of education [3], [13]. The returns to primary schooling tend to be greater than returns to secondary and tertiary education [13]. In agriculture, evidence suggests positive effects of education on productivity among farmers using modern technologies, but less impact, as might be expected, among those using traditional methods. In Thailand, farmers with four or more years of schooling were three times more likely to adopt fertilizer and other modern inputs than less educated farmers [4]. Similarly, in Nepal, the completion of at least seven years of schooling increased productivity in wheat by over a quarter, and in rice by $13 \%$ [8]. Education is also an important contributor to technological capability and technical change in industry. Statistical analysis of the clothing and engineering industries in Sir Lanka showed that the skill and education levels of workers and entrepreneurs were positively related to the rate of technical change of the firm [6]. Education alone of course cannot transform an economy. The quality and quantity of investment, domestic and foreign, together with the overall policy environment, form the other important determinants of economic performance. Yet the level of human development has a fairing on these factors too. The quality of 
policy making and of investment decisions is bound to be influenced by the education of both policy makers and managers. According to [14], for example, the higher the level of education of the work force the higher the overall productivity of capital because the more educated are more likely to be innovative and thus affect everyone's productivity. This implies that increased education of individuals raises not only their own productivity but also that of others with whom they interact, so that total productivity increases as the average level of education rises. The impact of education on the nature and growth of exports, which, in turn, affect the aggregate growth rate, is another way in which human development influences a country's performance. The education and skills of a developing country's force influence the nature of its factor endowment and consequently the composition of its trade. It has been argued that even unskilled workers in a modern factory normally need the literacy, numeracy, and discipline, which are acquired in primary and lower secondary school [14].

\section{Education and Income}

There is also a positive feedback from improved education to greater income equality, which, in turn, is likely to favour higher rates of growth. As education becomes more broadly based, low-income people are better able to seek out economic opportunities. For example, a study of the relation between schooling, income inequality and poverty in 18 countries of Latin America in the 1990s found that one quarter of the variation in workers' incomes was accounted for by variations in schooling attainment; it concludes that 'clearly education is the variable with the strongest impact on income equality' [17]. Another study suggested that a one percent increase in the labour force with at least secondary education would increase the share of income of the bottom 40 and $60 \%$ by between 6 and $15 \%$ respectively [9]. An investigation of the determinants of income distribution in 36 countries found secondary enrolment rates to be significant [10]. Education may affect per capita income growth via its impact on the denominator, i.e. population growth. For example, a study of fourteen African countries for the midnineties showed a negative correlation between female schooling and fertility in almost all countries, with primary education having a negative impact in about half the countries and no significant effects in the other half, while secondary education invariably reduced fertility [18]. The three success countries in terms of reduced fertility, Kenya, Botswana, and
Zimbabwe, had the highest levels of female schooling as well as the lowest child mortality rates [16].

\section{Education and Trade}

Some countries have successfully combined openness and investment in learning and education, forming a virtuous circle; openness creates demand for education, and learning and education make a country's export sector more competitive. Knowledge accumulation influences a country's trade performance and competitiveness [7], trade in turn, enhances knowledge accumulation, especially through imports. [4], observed that a World Bank study found that economic growth rates in a sample of 60 developing countries during 1985-95 were especially high where there was a combination of a high level of education and macroeconomic stability and openness. The impact of trade openness on longterm growth thus depends on how well people are able to absorb and use the information and technology made available through trade and foreign investment. It seems to be widely accepted that in order to adapt to an environment of stronger competition and to a world emphasizing the role of information, knowledge and skills, and advanced economies, there is the need to continuously upgrade the overall quality of their labour force through education. This may assist to consequently their poverty or totally eradicate it.

\section{Education and the Family}

The family is the foundation of a good society and of economic success. Families have differed over time, but they are still very important in the modern economy. To understand human capital, one has to go back to the family, because it is families that are concerned about their children and try, with whatever resources they have, to promote their children's education and values. Families are the major promoters of values in any free society and even in not-so-free societies. Families make a variety of decisions. One is whether to have many children or to have fewer children. Every nation that has developed has done that, some in remarkably short periods of time. Taiwan, for example, has a birth rate lower than the United State. Declining birth rates also characterize Hong Kong, Mexico, and Poland [2]. In the developed part of Turkey the average number of children that families have is lower than the less developed part. This is related with the level of education of families. On average, educated families, particularly educated women, have 1.4 children and uneducated families have 5.1 children 
in the eastern region of Turkey [1]. Thus in order to reduce the birth rate and inequalities between these regions of Turkey, more importance may have to be given to education. Greater education of parents, perhaps of mothers, tends to improve the treatment of children, especially the daughters. The gap between the education of sons and daughters seems to be smaller when parents are more educated. More educated men and women also tend to invest more in their own health and the health of their children. Indeed, education may be the single most important personal determinant of a person's health and life expectancy. According to [2], the educated persons in the United States and other rich nations are the least likely to smoke. He observed that smoking in the United States is now found in significant numbers only among those with no college education, and is especially common among high school dropouts. The educated persons in Turkey are mostly working most of the time. The uneducated people not in work usually sit in cafes and waste their times and many of them smoke [1]. Education of the poor helps improve their food intake not only by raising their incomes and spending on food but also by inducing them to make better, healthier, choices. Studies from different nations indicate that educated persons tend to consume a healthier diet even when the total amount spent on food is held constant [3], of course, the relation between education and better health and life expectancy involves causation in both directions, for grater health and lower mortality also induce larger investments in education and other human capital since rates of return on these investments are greater when the expected amount of working time is greater. It therefore seems to be widely accepted that, in order to achieve an environment that favours human advancement, and equality, the education of the citizens is paramount and this seems to be the only way to alleviate and totally eradicate poverty in any nation.

\section{Recommendations}

The cumulative and entrenched damage that been done to Nigeria educational sector and the specific damage done to University education today need to be resisted by Nigeria patriots. Presently, Nigeria universities are, in many fundamental respects, far below the standard of what university system ought to be. This has not always been so, because Nigeria universities have had their glorious days of decency, respectability and intellectual prowess. However, cursory observations show that since the mid-1980's, the university system witnessed almost exponential unplanned growth and chronic under funding, neglect of condition of work, as well as conditions of service. With dilapidated facilities, discontented staff and frustrated students, aggressive and violent tendencies festered and crises ensued, especially when the federal and state governments came to be perceived (rightly or wrongly) by staff and students as insincere in their approach in handling of demands for reform. However, these crises can be resolved and permanent solution found for them. The governments - federal and state should seek a proper understanding of the key issues involved rather than pay lip and political services to the problems. Though the issues are many and intertwine in a complex manner, they can be disaggregated for ease of comprehension if they are sincere. These issues have arisen in the context of long period of neglect of the system, the resulting piling up of problems and the accompanying frustration by those within the system over government's insincerity and inability to decisively address them. As part of solving these problems, the process of establishing universities should take into account the needs of the country not only from the point of view of increasing enrolments in universities, but also by ensuring that unnecessary duplications of programmes are avoided. Programmes should focus on areas that would promote advancement in technology and economic development. In the same vein, the National University Commission (NUC) which is the highest body in the administration of the universities, should be remodelled to serve the needs of the universities rather than that of the government. The commission should be allowed to operate independent of government interference and actually serve as buffer and a catalyst in promoting the cause of universities in all entire ramifications. According to the registrar of the Joint Admission Matriculation Board (JAMB) [11], "only $12 \%-15 \%$ of those qualify secure admission into the universities, JAMB cannot admit many who are qualify because of the weak institutional carrying capacity to absorb demand." His statement confirms the deteriorated conditions of Nigeria higher institutions of learning. Governments should as a matter of urgency, increase the funds allocated to capital expenditure in the universities and other arms of education. Cursory observations show that over $80 \%$ of funds in most universities go to salaries and wages; while an insignificant amount goes to over head, and much less to capital projects, training and research. The era in which government are comfortable making meagre salary increases to avert staff strike without commensurate funding of infrastructure and facilities should be done away with in the interest of our economy. It is also advocated that adequate fund should be made available for research into the production of food 
crops and live stock in Nigeria universities to reflect the peculiarities of their geographical locations. This would by no means enhance food security and reduce over dependence on crude oil as the only source of income. Likewise extensive education of farmers should be encouraged to take place in the universities on part time basis in such areas as; production techniques, use of fertilizer, seed stock, machinery, marketing and storage facilities. The government is also advised to adequately fund the current entrepreneur training programmes in the universities so that the aim and objectives of the establishment can be achieved.

\section{Conclusion}

Where poverty is the way of life, people's potential is often overshadowed by struggle to survive. But when equipped with education, which is the right tool, even the most, vulnerable are able to change their world and create better future for their children and consequently the nation at large.

\section{References}

[1] K. Baloglu. Economic Recovery Strategy for Wealth and Employment Creation. Journal of Economic Research, (1998)_77(13), 208-301.

[2] G.S. Becker, Human capital and Poverty, Religion and Liberty. Archive, Chicago: University of Chicago Press, (2008).

[3]. B.L. Behrman, How does Mother Schooling Affect the Family's Health, Nutrition, Medical care Usage and Household? Journal of Econometrics, (1999), 36 (2), 8796.

[4] N. Birdsall. Social Development, World Bank Policy research Working Papers. WPS 1123. Washington D.C., (2003).

[5] P. Bowman. Total quality management: An introductory Text. London: Prentice Hall, (2010).

[6] S. Deraniyagal. Technical, Change and Efficiency in Srilanka's manufacturing Industry. Oxford: Oxford University Press, (2005)

[7] G.I.N Emezue, But for ASSU'S Struggle: deregulation and Funding of University The National Scholar, Nigeria (2009).6 (1), 25-29.

[8] D. Jamision \& P. Moock, Farmer Education and Farmer Efficiency in the Nepal: The Role of Schooling, World Development,(2004), 42 (3), 205-218.
[9] S. Jegede, Education, UNESCO ranking: Dons flays Poor Government funding, (October 20, 2013), Sunday punch, Nigeria, P. 67.

[10] R. Lucas, Schooling, Earning and Experience. New York: Colombia University Press, (2008).

[11] D. Ojerinde Education: 1.2m UTME candidates Won't gain admission, April 28, Punch, Nigeria (2013), P.5.

[12] S.K. Ozturk. Investment in human capital. American Economic Review (2011), 51 (1), 334-342.

[13] G. Psacharopoulo. Returns to investment in Education: A global Update. World Development, (1998), 22 (1), 202-209.

[14] L. Roberts, Mechanics of Economic development, Journal of Monetary Economics (2011). 22 (1), 202-209.

[15] J.D. Sachs, The end of Poverty Economic Possibilities of our time, New York: The Penguin Press. (2009).

[16] A. Umukoro, education; UNESCO ranking: Dons flays Poor Government funding, October 20, Sunday punch, (2013), P. 67.

[17] UNESCO. Forum Mondiale Sur L' Education, Rapport Final, Dakar, Senegal du 26 au 28 April, (2011).

[18] World Bank Levelling The Playing Field: Giving girls equal chance for basic education: Washington D.C: The World Bank (2012). 